\title{
Polymorphisms in the leptin gene promoter in Brazilian beef herds
}

\author{
R.C. Guimarães ${ }^{1}$, J.S.N. Azevedo ${ }^{2}$, S.C. Corrêa ${ }^{1}$, J.E.G. Campelo ${ }^{3}$, \\ E.M. Barbosa ${ }^{4}$, E.C. Gonçalves ${ }^{5}$ and E. Silva Filho ${ }^{1}$ \\ ${ }^{1}$ Laboratório de Genética Animal do Instituto de Saúde e Produção Animal, \\ Universidade Federal Rural da Amazônia, Belém, PA, Brasil \\ ${ }^{2}$ Laboratório de Biologia do Campus de Capanema, \\ Universidade Federal Rural da Amazônia, Capanema, PA, Brasil \\ ${ }^{3}$ Laboratório de Melhoramento Animal do Departamento de Zootecnia, \\ Universidade Federal do Piauí, Teresina, PI, Brasil \\ ${ }^{4}$ Laboratório Interdisciplinar do Campus Mazagão, \\ Universidade Federal do Amapá, Mazagão, AP, Brasil \\ ${ }^{5}$ Laboratório de Tecnologia Biomolecular do Instituto de Ciências Biológicas, \\ Universidade Federal do Pará, Belém, PA, Brasil \\ Corresponding author: E. Silva Filho \\ E-mail: silva.filho@ufra.edu.br \\ Genet. Mol. Res. 15 (4): gmr15048981 \\ Received July 20, 2016 \\ Accepted October 7, 2016 \\ Published December 2, 2016 \\ DOI http://dx.doi.org/10.4238/gmr15048981
}

Copyright (C) 2016 The Authors. This is an open-access article distributed under the terms of the Creative Commons Attribution ShareAlike (CC BY-SA) 4.0 License.

ABSTRACT. Brazil is the world's largest producer of beef cattle; however, the quality of its herds needs to be improved. The use of molecular markers as auxiliary tools in selecting animals for reproduction with high pattern for beef production would significantly improve the quality of the final beef product in Brazil. The leptin gene has been demonstrated to be an excellent candidate gene for bovine breeding. The objective of this study was to sequence and compare the leptin gene promoter of Brazil's important cattle breeds in order to identify 
polymorphisms in it. Blood samples of the Nellore, Guzerat, Tabapuã, and Senepol breeds were collected for genomic DNA extraction. The genomic DNA was used as a template for polymerase chain reaction (PCR) to amplify a 1575-bp fragment, which in turn was sequenced, aligned, and compared between animals of different breeds. Twentythree single nucleotide polymorphic sites, including transitions and transversions, were detected at positions $-1457,-1452,-1446,-1397$, $-1392,-1361,-1238,-963,-901,-578,-516,-483,-478,-470,-432,-430$, $-292,-282,-272,-211,-202,-170$, and -147. Additionally, two insertion sites at positions -680 and -416 and two deletion sites at positions - 1255 and -1059 were detected. As the promoter region of the leptin gene has been demonstrated to vary among breeds, these variations must be tested for their use as potential molecular markers for artificial selection of animals for enhanced beef production in different systems of bovine production in Brazil.

Key words: Molecular markers; Animal breeding; SNP; Gene promoter; Candidate gene

\section{INTRODUCTION}

Brazil is considered the largest producer of beef in the world. However, it faces several challenges in improving the quality of the final product. Among the numerous challenges, two in particular should be emphasized: 1) the selection of animals with high reproductive and productive patterns and 2) management techniques for bovine production in variable grass systems, i.e., grass production with optimal adaptability and high nutritional value and adaptation of animals to different climatic conditions and sanitary control (Ferraz and Felício, 2010).

Fontanesi et al. (2014) have emphasized the use of molecular markers as a tool for assisting the selection of animals with excellent phenotypes to determine herd quality. The two main characteristics of the beef cattle are 'precocity', i.e., the accelerated growth and pubertal maturity that possibly leads to a shortened generational interval (Andrea et al., 2011) and 'flavor', i.e., the tenderness and juiciness of meat. These two traits are the most important requirements of the beef cattle market (Hunt et al., 2014).

Leptin is considered a multifunctional hormone that not only acts in the homeostasis of body weight, but also thermogenesis, angiogenesis, hematopoiesis, osteogenesis, chondrogenesis, both neurological and immunological functions, and blood pressure (Bouloumié et al., 1998; Fantuzzi and Faggioni, 2000; Mantzoros, 2000; Sagawa et al., 2002). A study on the reproductive performances of cows using molecular markers of the leptin gene concluded that this gene plays an important role in bovine pregnancy (Almeida et al., 2003) and weight gain performance (Almeida et al., 2007), and is also associated with the deposition of fat and tenderness of meat (Fortes et al., 2009).

The majority of research on genetic polymorphisms of the bovine leptin gene has been related to its exon and intron sequences and their relationship with the protein structure of leptin hormone. However, it has been reported that the polymorphisms found in the leptin gene promoter regulate the expression of leptin gene in fatty tissues and are associated with differences in serum leptin concentration, growth rate, body weight, food intake, feeding

Genetics and Molecular Research 15 (4): gmr15048981 
behavior, carcass measurements and merit, and production and composition of milk in beef cattle (Nkrumah et al., 2005). Therefore, the objectives of this study was to sequence a 1575bp fragment of the leptin gene promoter in the Nellore, Tabapuã, Guzerat, and Senepol breeds, and compare these sequences to find out which breeds stand out for their high relevance in beef production in Brazil.

\section{MATERIAL AND METHODS}

This study was evaluated and approved by the Ethics Committee for the Use of Animals in Experiments (CEUA) of Universidade Federal Rural da Amazônia (UFRA), Pará, Brazil, under the protocol numbers UFRA 02384.007128/2013-40 and CEUA 024/2016. All procedures were performed in accordance with the regulations of the National Council for Animal Experimentation Control, Brazil.

\section{Sampling and laboratory procedures}

A total of 180 animals were used in this study. Of these, 40 animals, each of the Nellore and Guzerat breeds, were obtained from the farmers of Imperatriz, State of Maranhão; 70 animals of the Tabapuã breed from Paragominas, State of Pará; and 30 animals of the Senepol breed from Uberlândia, State of Minas Gerais in Brazil. Five milliliters of blood from the jugular vein of each animal was collected in a tube containing EDTA.

Blood samples were hemolyzed with bi-distilled water and centrifuged for $5 \mathrm{~min}$ at $2000 \mathrm{~g}$ in order to separate the leukocytes, which were used for the genomic DNA extraction using phenol-chloroform-isoamyl alcohol method (Sambrook et al., 1989).

Polymerase chain reactions (PCR) were performed in order to amplify the 1575 bp fragments of the leptin gene promoter from the genomic DNA of different animals. A primer pair was designed on the basis of the GenBank reference sequence of Bos taurus leptin promoter (GenBank accession No. AJ571671) using the Primer3 program (http://bioinfo.ut.ee/ primer3-0.4.0/). The primer sequences were: forward 5'-AGGCGGAGAGGAGGAAAGAT-3' and reverse 5'-CCTCTTATAGCCGCCGAAG-3'. PCR was performed in a reaction volume of $25 \mu \mathrm{L}$ comprising the following reagents: 10X PCR buffer, $1 \mathrm{mM} \mathrm{MgCl}_{2}, 1.25 \mathrm{mM}$ each dNTP, $10 \mathrm{nM}$ each primer, 20\% betaine, 2 U Platinum High-Fidelity Taq DNA polymerase (Invitrogen, Carlsbad, CA, USA), and 50 to $100 \mathrm{ng}$ genomic DNA. The following reaction conditions were used: initial denaturation at $95^{\circ} \mathrm{C}$ for $10 \mathrm{~min}$, followed by 30 cycles of denaturation at $94^{\circ} \mathrm{C}$ for $1 \mathrm{~min}$; annealing at $53^{\circ} \mathrm{C}$ for Nellore and Tabapuã DNA, $55^{\circ} \mathrm{C}$ for Senepol DNA, and $58^{\circ} \mathrm{C}$ for Guzerat DNA for $45 \mathrm{~s}$; and extension at $72^{\circ} \mathrm{C}$ for $1 \mathrm{~min} 30 \mathrm{~s}$. Final extension was carried out at $72^{\circ} \mathrm{C}$ for $10 \mathrm{~min}$.

The PCR products were visualized on $1.5 \%$ agarose gel stained with GelRed ${ }^{\mathrm{TM}}$ Nucleic Acid Stain (Biotium, Fremont, CA, USA). The samples with high pattern were purified by Illustra ${ }^{\mathrm{TM}}$ ExoProStar ${ }^{\mathrm{TM}}$ one-step enzyme (GE Healthcare Life Sciences, Pittsburgh, PA, USA). Subsequently, all purified samples were sequenced using BigDye Direct Sanger Sequencing Kit (Invitrogen) by an automatic DNA sequencer ABI 3500xl (Applied Biosystems, Foster City, CA, USA).

\section{Sequence analysis}

The resulting DNA sequences were edited and aligned with the GenBank reference

Genetics and Molecular Research 15 (4): gmr15048981 
sequence AJ571671 using the BioEdit program (Hall, 1999; http://www.mbio.ncsu.edu/ bioedit/bioedit.html). All detected polymorphisms, insertions, and deletions were compared among different breeds. The allele frequencies were determined by direct counting.

\section{RESULTS}

After several attempts to amplify the 1575-bp fragment from all blood samples collected, isolated fragments of the leptin gene promoter were obtained from 40 Nellore, 70 Tabapuã, 40 Guzerat, and 29 Senepol animals. Of these, 39 animals were successfully sequenced: 12 Nellore, 10 Tabapuã, 11 Guzerat, and 6 Senepol. Subsequently, the sequence alignment of the DNA sequence of these animals with the GenBank reference sequence AJ571671 led to the identification of 23 single nucleotide polymorphisms (SNPs) in the region between positions -1442 and -133 of the leptin gene promoter in the bovine breeds. Of these SNPs, 14 were transition and 8 were transversion types. An SNP at position -170 might be a transition or transversion (Table 1). Varying numbers of SNPs were found in each breed: 13 Guzerat, 1 Nellore, 15 Senepol, and 9 Tabapuã.

Table 1. SNPs detected in the leptin gene promoter of the four beef bovine breeds from Brazil, their allele frequencies, and comparison with the reference sequence of Bos taurus leptin gene promoter (GenBank accession No. AJ571671).

\begin{tabular}{|c|c|c|c|c|c|}
\hline Positions & AJ571671 & Guzerat & Nellore & Senepol & Tabapuã \\
\hline-1457 & $\mathrm{~A}$ & $\mathrm{G}(0.27)$ & $\mathrm{A}$ & $\mathrm{G}(0.33)$ & $\mathrm{G}(0.17)$ \\
\hline-1452 & $\mathrm{~A}$ & $\mathrm{G}(0.55)$ & A & $\mathrm{G}(0.33)$ & $\mathrm{G}(0.17)$ \\
\hline-1446 & $\mathrm{~T}$ & $\mathrm{~T}$ & $\mathrm{~T}$ & $\mathrm{C}(0.33)$ & $\mathrm{T}$ \\
\hline-1397 & $\mathrm{~A}$ & $\mathrm{~A}$ & A & $\mathrm{T}(0.17)$ & $\mathrm{A}$ \\
\hline-1392 & $\mathrm{G}$ & $\mathrm{G}$ & $\mathrm{G}$ & $\mathrm{A}(0.33)$ & $\mathrm{A}(0.17)$ \\
\hline-1361 & G & G & G & $\mathrm{A}(0.17)$ & G \\
\hline-1251 & $\mathrm{~T}$ & $\mathrm{~T}$ & $\mathrm{~T}$ & $\mathrm{~T}$ & $\mathrm{~T}$ \\
\hline-1238 & $\mathrm{G}$ & G & G & $\mathrm{C}(0.33)$ & $\mathrm{C}(0.17)$ \\
\hline-963 & $\mathrm{C}$ & $\mathrm{C}$ & $\mathrm{C}$ & $\mathrm{T}(0.33)$ & $\mathrm{T}(0.17)$ \\
\hline-901 & $\mathrm{~A}$ & $\mathrm{~A}$ & A & $\mathrm{T}(0.33)$ & A \\
\hline-578 & $\mathrm{C}$ & $\mathrm{G}(0.45)$ & $\mathrm{C}$ & $\mathrm{G}(0.33)$ & $\mathrm{C}$ \\
\hline-516 & $\mathrm{~T}$ & $\mathrm{~T}$ & $\mathrm{~T}$ & $\mathrm{~T}$ & $\mathrm{~A}(0.17)$ \\
\hline-483 & $\mathrm{G}$ & $\mathrm{A}(0.36)$ & G & G & G \\
\hline-478 & $\mathrm{C}$ & $\mathrm{T}(0.41)$ & $\mathrm{C}$ & $\mathrm{C}$ & $\mathrm{C}$ \\
\hline-470 & $\mathrm{~A}$ & $\mathrm{~T}(0.09)$ & A & $\mathrm{A}$ & A \\
\hline-432 & $\mathrm{~A}$ & $\mathrm{G}(0.09)$ & $\mathrm{A}$ & $\bar{A}$ & $\bar{A}$ \\
\hline-430 & $\mathrm{G}$ & $\mathrm{C}(0.09)$ & G & G & G \\
\hline-292 & $\mathrm{~T}$ & $\mathrm{C}(0.55)$ & $\mathrm{T}$ & $\mathrm{C}(0.33)$ & $\mathrm{T}$ \\
\hline-282 & $\mathrm{G}$ & $\mathrm{T}(0.55)$ & G & $\mathrm{G}$ & $\mathrm{G}$ \\
\hline-272 & $\mathrm{G}$ & $\mathrm{G}$ & $\mathrm{G}$ & $\mathrm{A}(0.33)$ & $\mathrm{A}(0.17)$ \\
\hline-211 & A & $\mathrm{G}(0.55)$ & A & A & A \\
\hline-202 & $\mathrm{G}$ & $\mathrm{A}(0.36)$ & $\mathrm{A}(1.00)$ & $\mathrm{A}(0.17)$ & $\mathrm{A}(0.33)$ \\
\hline-201 & $\mathrm{C}$ & $\mathrm{C}$ & $\mathrm{C}$ & $\mathrm{C}$ & $\mathrm{C}$ \\
\hline-170 & $\mathrm{C}$ & $\mathrm{C}$ & $\mathrm{C}$ & $\begin{array}{l}\mathrm{A}(0.17) \\
\mathrm{T}(0.17)\end{array}$ & $\mathrm{C}$ \\
\hline-147 & $\mathrm{C}$ & $\mathrm{T}(0.55)$ & $\mathrm{C}$ & $\mathrm{T}(0.33)$ & $\mathrm{T}(0.17)$ \\
\hline
\end{tabular}

Both deletions and insertions were found at some sites. An insertion at position -680 was found only in the Tabapuã breed, while the insertion at position -415 was found in the Guzerat, Senepol, and Tabapuã breeds; however none were observed in the Nellore breed. Deletions were observed at position -1255 in both Senepol and Tabapuã breeds, while a deletion at position -1059 was found in all breeds (Table 2).

Genetics and Molecular Research 15 (4): gmr15048981 
Table 2. Insertions and deletions detected in the leptin gene promoter of the four beef bovine breeds from Brazil, their allele frequencies, and comparison with the reference sequence of Bos taurus leptin gene promoter (GenBank accession No. AJ571671).

\begin{tabular}{l|c|c|c|c|c}
\hline Positions & AJ571671 & Guzerat & Nellore & Senepol & Tabapuã \\
\hline Insertions & & & & & \\
\hline-680 & CTA & & & & CTTA $(0.17)$ \\
\hline-416 & GGT & GGGT $(0.50)$ & & GGGT $(0.33)$ & GGGT $(0.17)$ \\
\hline Deletions & & & & & \\
\hline-1255 & AG & & & AG $(0.33)$ & AG $(0.17)$ \\
\hline-1059 & TGT & TGT $(0.83)$ & TGT $(1.00)$ & TGT $(0.67)$ & TGT $(0.83)$ \\
\hline
\end{tabular}

\section{DISCUSSION}

The bovine leptin gene promoter demonstrated a high degree of polymorphism. This has also been noted by Liefers et al. (2005) and Nkrumah et al. (2005). A total of 25 polymorphic sites were detected in the 1600-bp long fragment of the leptin gene. On an average, this corresponded to one SNP per 52 bp. Liefers et al. (2005) analyzed a 1600-bp fragment of the leptin gene promoter in a Holstein-Friesian mixed breed and found 20 polymorphic sites, with an average of one SNP per 80 bp. Furthermore, Nkrumah et al. (2005) detected SNPs at positions $-207(\mathrm{C} \rightarrow \mathrm{T}),-528(\mathrm{C} \rightarrow \mathrm{T})$, and $-1759(\mathrm{C} \rightarrow \mathrm{G})$ in the leptin gene promoter using the GenBank reference sequence AB070368.1. None of these polymorphisms were found in our study, or in that of Liefers et al. (2005).

The SNP A1457G, previously identified in the Holstein breed by Liefers et al. (2005), was present among all Nellore samples in our study. However, the mean frequency among the others breeds was consistent with the findings of da Silva et al. (2012). On the other hand, the SNP at position -1457 showed no significant association with both growth and carcass traits in Nellore cattle (Silva et al., 2014). Although the Nellore breed shared almost $100 \%$ of its sequence with the sequence described by Taniguchi et al. (2002), some novel polymorphisms were observed in a mixed herd of the Holstein-Friesian breed studied by Liefers et al. (2005). Insertions at both positions -680 and -416 were characteristic of the Tabapuã breed, while insertion at only position -416 was detected in the Guzerat and Senepol breeds. Besides these insertions, a GenBank reference sequence AB070368.1 shows an insertion of cytosine (C) at position -498, which was not observed in our sequences, as well as in the sequences of Taniguchi et al. (2002) and Liefers et al. (2005). The Senepol and Tabapuã breeds presented the same deletion of two base pairs (AG) at position -1255. Likewise, Liefers et al. (2005) observed these insertions in a mixed-breed herd of Holstein-Friesian. However, the four breeds in our study have demonstrated a deletion of three base pairs (GTG) at position -1057, in consistency with the sequences of Taniguchi et al. (2002) and Liefers et al. (2005).

Most of the polymorphisms described in this study are highly relevant for leptin expression and may be associated with the characters of reproduction and production, which are the important characteristics of several bovine breeds of beef cattle in Brazil. Therefore, it is important to further analyze these leptin gene promoter polymorphisms as potential molecular markers for assisted artificial selection. The detection of such polymorphisms would likely be helpful in the development of breeds with enhanced production characteristics in different beef production systems in Brazil.

\section{Conflicts of interest}

The authors declare no conflict of interest.

Genetics and Molecular Research 15 (4): gmr15048981 


\section{ACKNOWLEDGMENTS}

We are grateful to all farm producers from Maranhão, Minas Gerais, and Pará States, who provided samples for this study. We also extend our gratitude to the staff of Laboratório de Tecnologia Biomolecular, Universidade Federal do Pará for allowing the use of their laboratory facilities.

\section{REFERENCES}

Almeida SEM, Almeida EA, Moraes JCF and Weimer TA (2003). Molecular markers in the LEP gene and reproductive performance of beef cattle. J. Anim. Breed. Genet. 120: 106-113. http://dx.doi.org/10.1046/j.1439-0388.2003.00377.x

Almeida SEM, Almeida EA, Terra G, Neves JP, et al. (2007). Association between molecular markers linked to the Leptin gene and weight gain in postpartum beef cows. Cienc. Rural 37: 206-211. http://dx.doi.org/10.1590/S0103$\underline{84782007000100033}$

Andrea MV, Gomes MVM, Marcondes CR, Oliveira KN, et al. (2011). Relação entre polimorfismo do gene do hormônio do crescimento e características de precocidade em novilhas da raça Nelore. Arq. Bras. Med. Vet. Zootec. 63: 153157. http://dx.doi.org/10.1590/S0102-09352011000100023

Bouloumié A, Drexler HCA, Lafontan M and Busse R (1998). Leptin, the product of Ob gene, promotes angiogenesis. Circ. Res. 83: 1059-1066. http://dx.doi.org/10.1161/01.RES.83.10.1059

da Silva RC, Ferraz JBS, Meirelles FV, Eler JP, et al. (2012). Association of single nucleotide polymorphisms in the bovine leptin and leptin receptor genes with growth and ultrasound carcass traits in Nellore cattle. Genet. Mol. Res. 11: 3721-3728. http://dx.doi.org/10.4238/2012.August.17.10

Fantuzzi G and Faggioni R (2000). Leptin in the regulation of immunity, inflammation, and hematopoiesis. J. Leukoc. Biol. 68: 437-446.

Ferraz JBS and Felício PE (2010). Production systems-an example from Brazil. Meat Sci. 84: 238-243. http://dx.doi. org/10.1016/j.meatsci.2009.06.006

Fontanesi L, Calò DG, Galimberti G, Negrini R, et al. (2014). A candidate gene association study for nine economically important traits in Italian Holstein cattle. Anim. Genet. 45: 576-580. http://dx.doi.org/10.1111/age.12164

Fortes MRS, Curi RA, Chardulo LAL, Silveira AC, et al. (2009). Bovine gene polymorphisms related to fat deposition and meat tenderness. Genet. Mol. Biol. 32: 75-82.

Hall TA (1999). BioEdit: a user-friendly biological sequence alignment editor and analysis program for Windows 95/98/ NT. Nucleic Acids Symp. Ser. 41: 95-98.

Hunt MR, Garmyn AJ, O'Quinn TG, Corbin CH, et al. (2014). Consumer assessment of beef palatability from four beef muscles from USDA Choice and Select graded carcasses. Meat Sci. 98: 1-8. http://dx.doi.org/10.1016/j. meatsci.2014.04.004

Liefers SC, Veerkamp RF, te Pas MF, Delavaud C, et al. (2005). Leptin promoter mutations affect leptin levels and performance traits in dairy cows. Anim. Genet. 36: 111-118. http://dx.doi.org/10.1111/j.1365-2052.2005.01246.x

Mantzoros CS (2000). Role of leptin in reproduction. Ann. N. Y. Acad. Sci. 900: 174-183. http://dx.doi. org/10.1111/j.1749-6632.2000.tb06228.x

Nkrumah JD, Li C, Yu J, Hansen C, et al. (2005). Polymorphisms in the bovine leptin promoter associated with serum leptin concentration, growth, feed intake, feeding behavior, and measures of carcass merit. J. Anim. Sci. 83: 20-28. http://dx.doi.org/10.2527/2005.83120x

Sagawa N, Yura S, Itoh H, Mise H, et al. (2002). Role of leptin in pregnancy--a review. Placenta 23 (Suppl A): S80-S86. http://dx.doi.org/10.1053/plac.2002.0814

Sambrook J, Fritsch EF and Maniatis T (1989). Molecular Cloning: a Laboratory Manual. 2nd edn. Cold Spring Harbor Laboratory Press, New York.

Silva DBS, Crispim BA, Silva LE, Oliveira JA, et al. (2014). Genetic variations in the leptin gene associated with growth and carcass traits in Nellore cattle. Genet. Mol. Res. 13: 3002-3012.http://dx.doi.org/10.4238/2014.April.16.9

Taniguchi Y, Itoh T, Yamada T and Sasaki Y (2002). Genomic structure and promoter analysis of the bovine leptin gene. IUBMB Life 53: 131-135.http://dx.doi.org/10.1080/15216540211465

Genetics and Molecular Research 15 (4): gmr15048981 